\title{
Organização e Ideologia nos Partidos da América Latina: uma Aproximação da Hipótese de Michels
}

\author{
Augusto Neftali Corte de Oliveira ${ }^{1}$ \\ 1Professor do Programa de Pós-Graduação em Ciências Sociais e do curso de bacharelado/licenciatura em \\ Ciências Sociais da Pontifícia Universidade Católica do Rio Grande do Sul (PUC-RS). Porto Alegre, RS, Brasil. \\ E-mail: augusto.oliveira@pucrs.br; ORCID: https://orcid.org/0000-0002-5615-8187
}

\section{INTRODUÇÃO}

As transformações dos partidos políticos em sua dimensão organizacional e ideológica é um objeto de interesse da Ciência Política desde a análise precursora de Michels e sua lei de ferro da oligarquia. Existe um esforço da literatura na área em associar estas duas dimensões para compreender se, e de que maneira, diferentes incentivos provenientes da organização influenciam as mudanças ideológicas dos partidos políticos. Em suas decorrências mais profundas, a lei de ferro da oligarquia revela a contradição do ideal democrático de um governo do próprio povo com os instrumentos eleitorais da representação política e, especialmente, com o papel dos partidos políticos. Em seu aspecto intermediário, a hipótese de que o desenvolvimento organizacional dos partidos favorece o abandono de suas proposições iniciais e a adoção de uma ideologia conservadora pode servir como ponto de partida para o estudo comparado das experiências políticas. Nesta perspectiva, a ideologia é tratada como um dos muitos recursos importantes para os partidos políticos no ambiente em que convivem com outras agremiações e no qual disputam por votos.

O estudo da conexão entre organização e ideologia possui uma longa trajetória em relação às democracias liberais do Ocidente. Documentaram-se as transformações das organizações políticas, em especial dos recursos que empregam na disputa eleitoral, e sua associação com o processo de perda da identidade ideológica e do enraizamento social. Não obstante, como salienta Ribeiro (2014), existem poucos esforços que tratam a lei de ferro como uma hipótese a ser testada empiricamente. Na América Latina a literatura é ainda menos

DADOS, Rio de Janeiro, vol.62(1):e20160258, 2019.

http://dx.doi.org/10.1590/001152582019173 
aprofundada, em especial sob o ponto de vista empírico, quando se trata desta conexão entre mudança organizacional e programática. A interpretação, preponderante para vários casos nacionais, de que os partidos operam de maneira socialmente pouco estruturada e recorrem a mecanismos de representação não programática - como o clientelismo, o patrimonialismo, o coronelismo - parece diminuir o interesse de pesquisa sobre a dinâmica organizacional e seus reflexos ideológicos.

Esta pesquisa busca avançar na compreensão sobre o fenômeno partidário latino-americano, ao investigar de maneira comparada a conexão entre desenvolvimento organizacional e mudança ideológica. Para isso, em seu aspecto teórico, utiliza uma apreensão parcial da lei de ferro da oligarquia. Segundo esta interpretação, a hipótese de Michels é lida como a prescrição de que os partidos políticos, quando se tornam organizacionalmente mais complexos - maiores e mais velhos -, abandonam sua ideologia inicial em favor de uma mais moderada. Trata-se, portanto, de um processo de desideologização (em breve discutido com maior profundidade).

Em seu esforço empírico, a pesquisa baseia-se em informações de 62 partidos políticos latino-americanos que participaram de 49 eleições presidenciais em 12 países da América Latina entre 1998 e 2015. A questão organizacional foi apreendida a partir de quatro indicadores do tempo de funcionamento das agremiações e do tamanho de suas organizações. O perfil ideológico das agremiações foi traçado a partir de uma estratégia de análise de conteúdo dos programas de governo das eleições presidenciais. De acordo com a disponibilidade das fontes primárias $^{1}$, foram incluídos na pesquisa Argentina, Bolívia, Brasil, Chile, Equador, México, Colômbia, Costa Rica, El Salvador, Peru, Uruguai e Venezuela.

A pesquisa é operacionalizada com o auxílio de uma análise gráfica que permite inferir a adequação dos partidos à prescrição da lei de ferro da oligarquia. Revela-se que o comportamento dos partidos originalmente de esquerda aproxima-se da hipótese de Michels. Os partidos originalmente de esquerda com maior complexidade organizacional apresentam, de fato, uma ideologia programática menos radical, próxima do centro ideológico (entre a centro-esquerda e a centro-direita). Os menos complexos, coerentemente, articulam programas de governo ideologicamente mais radicais, à esquerda. 
A discussão realizada em seguida destaca a trajetória de alguns partidos de esquerda capturados no período da pesquisa. Desenvolve interpretações sobre fatores inerentes e extrínsecos à lei de ferro que podem ter influenciado nas trajetórias que se adequam e que divergem do pressuposto de Michels. Especialmente, destaca a condicionalidade da lei de ferro, na medida em que questões de estratégia dos líderes partidários podem favorecer ou vetar a adesão à moderação ideológica em agremiações com complexidade organizacional intermediária. Apresenta, também, uma interpretação provisória sobre a não verificação da ocorrência de lei de ferro no conjunto de partidos orginalmente de direita.

A aproximação que esta pesquisa realizada de uma leitura da hipótese de Michels para o contexto da América Latina recente permite, em certo sentido, atestar sua permanência enquanto elemento explicativo do comportamento das agremiações políticas. Especialmente para os partidos de esquerda - sobre os quais Michels dedica suas preocupações - a influência dos incentivos organizacionais compreendidos pela lei de ferro parece compor o quadro da desideologização.

\section{ORGANIZAÇÃO E IDEOLOGIA NOS PARTIDOS POLÍTICOS: A HIPÓTESE DE MICHELS REVISTA}

Os efeitos do desenvolvimento da organização partidária sobre sua ideologia política encontram-se no cerne da problemática discutida por Michels (1982). Com aportes de intérpretes posteriores, esta seção explora o argumento da lei de ferro da oligarquia com a finalidade de construir uma proposição de trabalho sobre a relação entre organização e ideologia nos partidos políticos. Discutem-se duas leituras desta relação: (a) como um problema de responsividade entre as opiniões dos chefes e dos membros dos partidos e (b) como um processo de desideologização, ou perda das características ideológicas originais por parte da agremiação. Embora muitas análises associem estas duas questões, elas se reportam a fenômenos distintos. A hipótese que conecta a mudança organizacional e desideologização dos partidos políticos é adotada como ponto de partida da presente investigação.

O argumento de Michels ressalta que, para disputar o poder nas sociedades de massas, os indivíduos não possuem alternativa além daquela de formar organizações. Como exigência da disputa de poder, 
decorre para os partidos bem-sucedidos o crescimento da organização, o aumento do número e a diversificação de seus membros. Suas atividades tornam-se mais complexas, na medida em que a organização assume interações no ambiente político. Surge a necessidade de uma gestão estratégica e rápida sobre desafios cotidianos cada vez mais intricados. Assim, a organização passa a concentrar a tomada de decisão em uma minoria de indivíduos que se especializam como seus gestores, uma burocracia de políticos profissionais ou técnicos da política. A divisão de trabalho divorcia a grande massa de membros daqueles chefes ${ }^{2}$, os quais buscam cristalizar o status diferenciado e controlar o acesso aos postos diretivos em um processo de oligarquização.

Na visão de um crítico (Hands, 1971), Michels deixa de demonstrar com precisão como identificar a oligarquização. Em parte das vezes o uso de oligarquia é empregado como a simples concentração de poder em um grupo de líderes. Uma segunda definição adiciona a exigência de que esta minoria possua interesses divergentes daqueles da massa de membros (maioria). A partir da posição privilegiada, os líderes dirigem a organização aos objetivos de poder da burocracia, relegando a defesa das políticas que respondem aos interesses da grande massa de seus membros ordinários. Neste sentido restrito, a oligarquização não importa apenas em um problema de quem exerce o poder dentro da organização, mas também na questão de quais os interesses perseguidos por estes líderes. Esta segunda interpretação do conceito, mais restrita, pode ser abordada de duas maneiras diferentes: como perda de responsividade ou como desideologização.

Diversos autores adotam a primeira posição e interpretam a lei de ferro da oligarquia no sentido de que o crescimento das organizações partidárias leva seus dirigentes a serem menos ou não responsivos aos membros inferiores. Na proposição inovadora de Cassinelli (1953), quando uma organização alcança certo tamanho e grau de complexidade, as pessoas que exercem a autoridade em função da posição que ocupam na organização são controladas pelas pessoas em posição de menor autoridade apenas de forma negativa. Isto é, pela estimativa sobre as reações que as decisões dos líderes causarão na base do partido. Foi, provavelmente, a partir da profícua investigação sobre a democracia em um sindicato americano empreendida em Lipset (2010 [1952]) que a responsividade dos líderes à base passou a predominar como cerne da lei de ferro ${ }^{3}$. 
May (1965) dissente desta interpretação. Ele argumenta que Michels aplica dois usos para a expressão democracia na organização partidária e, portanto, duas visões sobre o prejuízo implicado pela oligarquização. Ao lado da já referida (controle dos líderes pelos liderados), emprega democracia no sentido de uma conexão moral entre o partido e o objetivo da revolução socialista. Com o aumento da organização partidária em tamanho e complexidade, o que se perde é a condição democrática neste segundo sentido: os líderes abandonam o programa de transformação social radical por intenções reformistas ou conservadoras. May (1965:428) afirma, inclusive, que Michels não defende a possibilidade de os líderes manterem-se no poder contrariando as opiniões de seus constituintes. $\mathrm{O}$ desvio em tela estaria resumido a um abandono da doutrina socialista. Neste sentido, o deslocamento dos objetivos entabulado pela maior complexidade da organização se encerraria na desideologização da organização política.

Em sua conclusão, Michels apresenta três argumentos sintéticos da razão pela qual os partidos socialistas abandonam sua ideologia original. O primeiro recorre diretamente ao argumento do crescimento das organizações políticas. Pelos mecanismos já destacados, os objetivos de preservação e aumento de poder da própria organização suplantam os objetivos ideológicos como móbil da ação partidária: “à medida que a organização cresce, a luta pelos grandes princípios se torna impossível" (Michels, 1982:220). O segundo argumento destaca a dinâmica de um partido com atuação parlamentar, que se dedica a capturar um número cada vez maior de eleitores e mensura seu progresso pelo número de cadeiras obtidas. Nesse sentido, a necessidade do apoio de um eleitorado genérico é outro fator da desideologização, pois, "para não assustar estas pessoas que ainda estão afastadas do mundo ideal do socialismo ou da democracia, evita-se de praticar uma política de princípios" (Idem: 222).

A terceira causa da desideologização para Michels refere-se à conexão do partido com o Estado. O pressuposto original dos partidos socialistas de afecção marxista, ao crescerem em membros e acumular recursos, é suplantar o Estado existente em uma nova forma. Contudo, ao se tornarem importantes o suficiente para influenciar as decisões estatais, os partidos passam a garantir vantagens relativas para a classe (justiça social) e empregos moral e financeiramente gratificantes para seus chefes. Então, Michels argumenta que um partido que cresce enquanto participa do Estado nunca poderá - salvo situações 
excepcionais - lhe fazer frente, logo passará a restringir suas ideias e práticas àquelas que não arriscam as posições já alcançadas.

Das três causas destacadas, resulta uma relação que está bastante evidente para Michels, entre o crescimento do partido e o abandono de posições radicais em favor da moderação ideológica:

A consequência lógica dessa constatação se encontra, desse modo, em oposição direta com as esperanças que tinham concebido os fundadores do partido, quando ainda o tinham nas fontes do batismo. Em vez de ganhar em energia revolucionária, à medida que aumentam suas forças e a solidez de sua estrutura, o partido viu produzir-se no seu seio um fenômeno diametralmente oposto: nos referimos às relações íntimas que são constatadas entre o crescimento do partido e a timidez e prudência cada vez maiores, nos quais sua política se inspira. (Michels, 1982:222)

O elemento ideológico da oligarquização pode ser interpretado tanto como ausência de responsividade quanto como desideologização, reflexo de uma obra que ao longo de seus cem anos foi reinterpretada sob novas luzes. Em sua formulação original, a lei de ferro da oligarquia supõe que os dois processos são contemporâneos:

a oligarquização não se refere simplesmente ao fato de que os dirigentes passam a defender interesses próprios, diferenciados da base. É que eles se tornam conservadores, (...) traindo, com isso, os ideais que os ligavam àqueles que dizem representar" (Miguel, 2014:147).

Contudo, ambos os fenômenos podem ou não coexistir. Como aponta Leach (2005), a adesão a uma pauta relativamente reacionária pela liderança de um partido ou sindicato (desideologização) pode ser responsiva à opinião majoritária de seus membros, pois nada impede que exista na base da organização uma posição mais moderada daquela defendida inicialmente por seus líderes.

Inobstante esta ressalva, é bastante frequente a inferência de que os membros de base dos partidos políticos possuem interesses ideológicos mais sinceros, puros ou radicais do que seus líderes. Negar a interpretação da lei de ferro da oligarquia como expressão da distensão ideológica entre líderes e membros não impediu May (1973) de construir sua própria lei sobre o assunto. A lei da disparidade curvilínea 
indica que os membros dos partidos (líderes intermediários) teriam posições mais radicais do que seus líderes e apoiadores. O pressuposto da base radical também está presente na análise de Strøm (1990), ou na de Harmel e Janda (1994). Os autores associam a democratização interna dos partidos com o incremento da militância ideológica e a um partido mais voltado para defesa de políticas públicas com viés ideológico. Antes, Lipset (2010) identificou que os líderes de organizações expostas à competição podem adotar posturas radicais, contrariamente à premissa da lei de ferro, com o objetivo de reforçar o militantismo.

Diferentes noções de desideologização foram levantadas em abordagens fundamentais na Ciência Política, como em Lipset e Rokkan (1992), Przeworski e Sprague (1986), Kirchheimer (1980), Panebianco (2005) e Katz e Mair (1995). Essas análises se diferenciam da interpretação de Michels por ressaltarem aspectos externos à organização os quais - mesmo quando intermediados por ela - seriam os motivos em última instância para a desideologização ou a mudança ideológica em sentido amplo. Como destacado nas passagens acima, Michels não ignora o efeito de certos elementos exteriores, tal qual a competição e a atividade parlamentar, enquanto incentivos ao crescimento das organizações políticas ${ }^{4}$. Mas o argumento central do aspecto organizacional da lei de ferro da oligarquia responde à dinâmica interior que torna a organização mais complexa na medida em que cresce em número de membros. O conjunto de interpretações referido, embora não recorram apenas aos mecanismos de Michels, mostram como o insight de investigar a articulação da ideologia e a vida organizacional de um partido mantêm sua importância como objeto de estudo.

\section{MENSURAÇÃO DA COMPLEXIDADE ORGANIZACIONAL DOS PARTIDOS DA AMÉRICA LATINA: VARIÁVEL TEMPO-TAMANHO (V.TT)}

A partir da revisão anterior, adota-se a proposição de que o aumento da complexidade organizacional dos partidos políticos favorece sua desideologização. Esta seção apresenta um esforço de mensurar a complexidade organizacional dos partidos da América Latina no período de análise (1998-2015). Foram utilizados dois vetores para a análise organizacional: idade (tempo de duração) e tamanho. Na construção de seu argumento, Michels não confere ao tempo a mesma importância do que o tamanho. Mas o autor recorre diretamente ao tempo em algumas passagens, por exemplo, quando afirma que o partido "quando 
velho ou, se preferirmos, politicamente maduro, ele não hesitou em modificar sua primeira profissão de fé" (Michels, 1982:222). O tempo está principalmente inferido na oligarquização enquanto processo, na especialização dos membros e consolidação da divisão de tarefas.

Para sua operacionalização no contexto da América Latina, mesmo uma variável simples como o tempo de funcionamento exige um esforço de interpretação. A história de muitas agremiações é atravessada por períodos democráticos e autoritários, de atividade partidária regular, proscrição e clandestinidade. Para cobrir estas lacunas, a variável foi dividida em dois indicadores: (a) o número de anos corridos da fundação do partido e (b) o número de anos de funcionamento regular ininterrupto, contado da primeira eleição presidencial no período democrático atual.

Estruturas maiores, ao lado de duráveis, indicam um nível maior de complexidade: delas dependem um número maior de líderes, burocratas, funcionários, possivelmente dispostos a dar prioridade aos objetivos organizacionais frente aos objetivos ideológicos. Para mensurar o tamanho dos partidos, adotou-se como indicador o número de cadeiras que possui na câmara baixa ou única de seu país. Como aponta Panebianco (2005:422) ${ }^{5}$ a dimensão (tamanho) da bancada parlamentar do partido está conectada à sua grandeza eleitoral, como é evidente. Além disso, os partidos que possuem potencial de coalizão, ou seja, que são atores importantes seja na disputa eleitoral, seja na vida parlamentar, precisam lidar com um número maior de possíveis cursos de ação, o que torna mais complexas suas relações internas:

É possível supor ainda que, quanto maior o número de opções políticas que o partido tem diante de si na escolha das alianças parlamentares, na escolha do tipo de oposição ("dura", "branda" etc.), maiores são as tensões em seu interior. De fato, se as alternativas disponíveis são muitas, é provável que dentro do partido haja confronto entre mais grupos que proponham tantas "linhas políticas" diferentes quantas forem as alternativas disponíveis. A existência de muitas alternativas disponíveis torna "complexa" para o partido a arena parlamentar, a incerteza será aumentada e muitas serão as "receitas" propostas para enfrentá-la. (Panebianco, 2005:424)

Assim, como uma proxy para o tamanho da organização dos partidos políticos adota-se o número de representantes eleitos pela agremiação no pleito para a câmara baixa ou única que antecedeu o momento anali- 
sado. Dois valores foram coletados sobre o tema: (a) o número absoluto de representantes eleitos e (b) a proporção da bancada eleita no total de cadeiras em disputa. O primeiro indica um valor absoluto, que compatibiliza os diferentes casos nacionais. $\mathrm{O}$ segundo indica um valor relativo, da relevância do partido nos limites definidos em razão do contexto nacional em que atua. A opção pelos dois indicadores responde aos diferentes sistemas partidários legislativos (do bipartidarismo ao multipartidarismo) e às diferentes magnitudes dos legislativos latino-americanos.

Os quatro indicadores - anos da fundação do partido (a.fund); anos de funcionamento em regime democrático (a.dem); número absoluto de cadeiras da bancada na câmara baixa ou única (b.abs); proporção da bancada no total de cadeiras da câmara baixa ou única (b.prop) - foram utilizados para formar uma variável indicadora da complexidade organizacional: Variável Tempo-Tamanho (V.TT). Cada indicador foi computado até o valor máximo de 50. A V.TT possui uma variação de zero até 1 , respectivamente o menor e maior nível de complexidade. A seguinte expressão apresenta o cálculo do indicador:

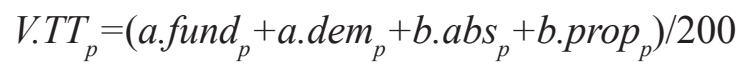

A definição dos limiares adotados é importante para o desenho da pesquisa. Michels (1982:233) afirma que a oligarquização do partido ocorre após seus membros "trabalharem durante meio século à custa do suor do front para criar uma organização modelo" e englobar "três milhões de trabalhadores, mais ainda do que se julgava necessário para alcançar sobre o inimigo uma vitória completa". Embora a referência seja alegórica, o transcurso de 50 anos parece adequado do ponto de vista de uma sucessão geracional. Uma maioria de membros na câmara baixa (50\%) indica ultrapassar um limiar relevante na relação de poder com os inimigos do partido, enquanto o número absoluto de 50 parlamentares, relativamente baixo para países como Brasil, México e Argentina, aproxima-se deste limiar para o conjunto de países com câmaras baixas de menor magnitude. Repare-se que, embora possa ser considerado o aspecto central desencadeador da oligarquização, Michels deixa de precisar a partir de qual quantidade os membros perdem a capacidade de dirigir o partido (Ribeiro, 2012:39).

A Figura 1 indica nos pontos os valores da V.TT para os partidos incluídos na pesquisa, conforme o ano em que disputaram a Presi- 
dência dos respectivos países. Nas linhas, exibe-se o valor médio da complexidade organizacional.

Figura 1

Complexidade organizacional (V.TT) dos partidos na América Latina, por país e ano de eleição presidencial (1998-2015)

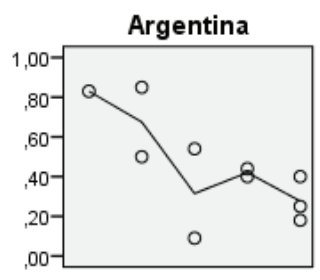

Bolívia
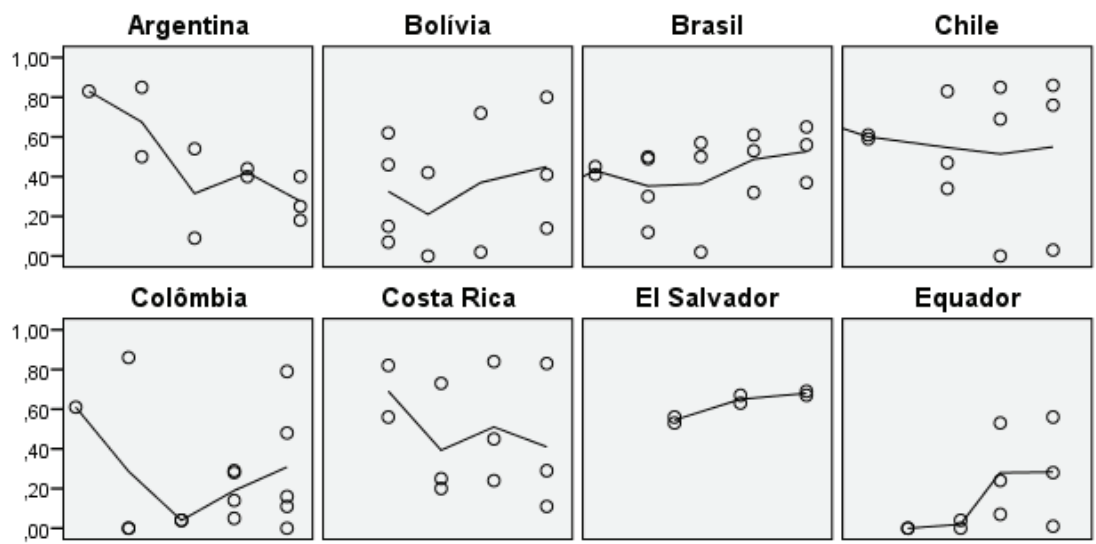

El Salvador

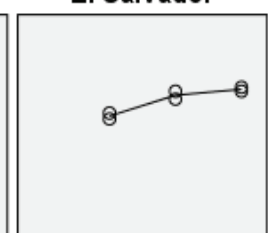

Equador

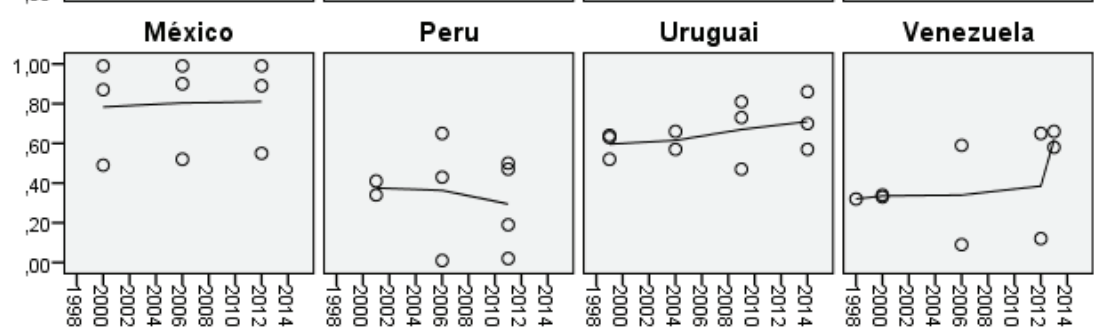

Fonte: Elaboração própria a partir de dados disponíveis em Oliveira (2016).

O uso dos indicadores de tamanho e de tempo de duração das agremiações respondem adequadamente à proposição original de Michels. Inegavelmente, contudo, o desenvolvimento posterior da análise organizacional das agremiações trouxe à consideração outros fatores. Uma medida da oligarquização por meio da não renovação dos dirigentes partidários foi formulada por Schonfeld (1980a; 1980b) e aplicada para agremiações brasileiras por Lucas (2000) e Ribeiro (2009). Repare-se que Schonfeld (1980b) admite que seu indicador não captura propriamente o processo de oligarquização partidária, no sentido de não ser uma causa nem necessária, nem suficiente para caracterizar o fenômeno, optando então por outra proposição teórica. Daí, também, que Ribeiro (2014) indique a adição de uma medida de falta de responsividade à noção de ausência de renovação. 
Panebianco (2005:387), em um contexto de análise mais amplo, apresenta indicadores relacionados diretamente com a especialização, a divisão de tarefas e a formalização dos procedimentos internos da organização. Pesquisas interessadas pelas agremiações políticas em cenários de consolidação democrática vêm realizando esforços no sentido de construir indicadores a partir de dados mais próximos aos trabalhados por Panebianco (Basedau e Stroh, 2008; Stauber, 2015). Deve-se anotar, contudo, que tais informações possuem uma sistematização mais complicada, dada a necessidade de recorrer à pesquisa de survey e/ou à pesquisa de campo em um contexto de baixa formalização dos procedimentos.

Para pesquisa comparada na América Latina, um esforço inicial foi empreendido por Sáez e Freidenberg (2001) e colaboradores. Došek (2016) organizou dados oficiais e de imprensa sobre membros e organizações partidárias latino-americanas, no que considera um esforço para suprir importante lacuna empírica. Em conclusão, constata elevada heterogeneidade entre os partidos da região e a necessidade de revalidar os dados disponíveis, pois há importantes inconsistências nas informações oficiais. Alguns fatores podem ser destacados para ressaltar a heterogeneidade política da América Latina: a diferença nos sistemas eleitorais (Marenco, 2012), nas regras de financiamento (Zovatto, 2005), nas relações entre os poderes (Grohmann, 2001). Diferenças como as citadas, em tese, implicam incentivos sobre a dinâmica intrapartidária. É forçoso reconhecer que a burocratização partidária está sujeita a outros critérios além do binômio tamanho/ idade. Nos termos de Michels, são lidos a partir da especialização em funções e por elementos psicológicos, por exemplo. Ressalva-se, assim, que o efeito de tamanho/idade do partido sobre as relações internas pode estar atrelado a outros fatores não inclusos na pesquisa.

\section{MENSURAÇÃO DA IDEOLOGIA PROGRAMÁTICA DAS CANDIDATURAS PRESIDENCIAIS NA AMÉRICA LATINA: A VARIÁVEL DE IDEOLOGIA (V.IDEO)}

O Banco de Asserções Programáticas (BAP), disponível em Oliveira (2016), coleciona e organiza a adesão dos partidos políticos da América Latina a proposições de políticas públicas (asserções), apreendidas por meio da análise de conteúdo dos programas de governo lançados nas candidaturas presidenciais. Esta iniciativa, cujos pressupostos metodológicos podem ser verificados em Oliveira (2015), visa preencher uma lacuna sobre a identificação ideológica dos partidos políti- 
cos na América Latina. A estratégia adotada baseia-se na presença ou ausência, no corpo de texto de cada programa de governo analisado, de asserções temáticas previamente definidas (Anexo 1).

As asserções consideradas no BAP limitam-se à temática econômica. Compreende-se que este recorte reduz o problema, embora possa ser argumentado - recuperando colocação de Downs (1999:137) - que a intervenção governamental na economia é a questão crucial da disputa ideológica entre os partidos nas democracias contemporâneas ${ }^{6}$. No contexto latino-americano abordado, a disputa ideológica central gira em torno da adesão e rejeição às prescrições neoliberais, resumíveis nos dispositivos do Consenso de Washington (Marangos, 2009; Rodrik, 2006; Przeworski, 1994). Tais prescrições envolvem medidas destinadas à adoção de disciplina fiscal, liberalização comercial, desregulamentação econômica e transferência de serviços sociais para o setor privado. Voltam-se para a proposição de um ambiente econômico mais eficiente, em uma linha interpretativa que associa este objetivo a menor intervenção governamental na economia.

No contraponto às políticas neoliberais, sublinha-se a defesa de medidas destinadas à segurança econômica por meio da intervenção governamental na economia. De maneira geral, recorre-se às noções que orientaram a socialdemocracia após Keynes, como a de política anticíclica, regulação das relações econômicas e proteção do emprego, expansão do bem-estar e do padrão de consumo nacional (Przeworski,1989:51). Outras ênfases trabalhadas capturam estratégias econômicas difundidas entre os países da América Latina. Uma delas pode ser resumida na visão do desenvolvimentismo, na qual o estado torna-se um ator ativo em favor da industrialização com características nacionais (Fonseca, 2004). Uma segunda estratégia é a da substituição de importação, que manipula o investimento público, a gestão de tributos, do câmbio e de barreiras administrativas para proteger a indústria nacional (Bruton, 1998).

O campo do neoliberalismo foi identificado como ideologicamente à direita e o campo pró-intervenção estatal, considerado ideologicamente à esquerda. Foram levantadas asserções de políticas públicas destes dois campos em cinco áreas de políticas públicas (comercial, fiscal, monetária e de gasto público, financeira e de regulação), conforme definições que seguem. 
Quadro 1

Conteúdo dos grupos de política pública, Banco de Asserções Programáticas

\begin{tabular}{|c|c|c|}
\hline $\begin{array}{l}\text { Banco de Asserções } \\
\text { Programáticas }\end{array}$ & $\begin{array}{c}\text { Direita } \\
\text { Neoliberalismo }\end{array}$ & $\begin{array}{c}\text { Esquerda } \\
\text { Intervenção Estatal }\end{array}$ \\
\hline Política Comercial & $\begin{array}{l}\text { Abertura comercial, tratados } \\
\text { comerciais. Privatização de } \\
\text { empresas. }\end{array}$ & $\begin{array}{l}\text { Protecionismo. Atividade } \\
\text { econômica do estado. } \\
\text { Nacionalização. }\end{array}$ \\
\hline Política Fiscal & Restrição à tributação. & $\begin{array}{l}\text { Aumento/progressividade da } \\
\text { tributação. }\end{array}$ \\
\hline $\begin{array}{l}\text { Política Monetária e } \\
\text { de Gasto Público }\end{array}$ & $\begin{array}{l}\text { Superavit/disciplina fiscal. } \\
\text { Restrição do gasto público. Acordo } \\
\text { com o FMI. Controle de inflação. }\end{array}$ & $\begin{array}{l}\text { Estímulo à demanda, ao mercado } \\
\text { interno. Socialismo, anti- } \\
\text { neoliberalismo. }\end{array}$ \\
\hline Política Financeira & $\begin{array}{l}\text { Investimento externo direto. } \\
\text { Liberdade do sistema financeiro, } \\
\text { privatização de bancos. }\end{array}$ & $\begin{array}{l}\text { Controle sobre a circulação de } \\
\text { capitais. Intervenção no sistema } \\
\text { financeiro, bancos públicos. }\end{array}$ \\
\hline $\begin{array}{l}\text { Política de } \\
\text { Regulação }\end{array}$ & $\begin{array}{l}\text { Desburocratização. Livre mercado. } \\
\text { Flexibilização das relações de } \\
\text { trabalho. Direitos de propriedade. }\end{array}$ & $\begin{array}{l}\text { Regulamentação de relações de } \\
\text { consumo. Regulamentação das } \\
\text { relações de trabalho. }\end{array}$ \\
\hline
\end{tabular}

Fonte: Oliveira (2015).

A partir do BAP é possível desenvolver diferentes maneiras de mensurar a ideologia programática das candidaturas presidenciais e dos partidos que as subsidiam. Na presente pesquisa, a ideologia programática foi tratada por meio do indicador V.Ideo. Seu objetivo é fornecer uma visão da ideologia programática em um eixo ideológico unidimensional (esquerda/direita), capaz de oferecer uma comparação entre os programas de governo de um país, entre os programas de diversos países e ao longo do tempo. Para neutralizar fatores como o tipo e o tamanho do documento (programa de governo), o cálculo adotado possui base no total de asserções presentes em cada programa - na fórmula expressada a seguir. Nela, "d" refere-se ao conjunto de asserções programáticas do campo de direita e " $\mathrm{e}$ " ao conjunto de asserções programáticas do campo de esquerda, conforme relacionado no Anexo 1. O V.Ideo possui variação entre -1 (valor máximo no campo de esquerda) e 1 (valor máximo no campo de direita), sendo que no zero expressa um programa de 
governo com presença equivalente de ênfases de ambos os campos (no centro ideológico).

$$
\text { V. Ideo }_{p}=\frac{\left(\sum_{i=1}^{n} d_{p, i}\right)-\left(\sum_{i=1}^{n} e_{p, i}\right)}{\left(\sum_{i=1}^{n} d_{p, i}\right)+\left(\sum_{i=1}^{n} e_{p, i}\right)}
$$

A Figura 2 apresenta, nos pontos, o valor de V.Ideo do programa de governo de cada partido que participou de disputa presidencial, por ano de eleição. As linhas marcam a trajetória dos partidos que apresentaram duas ou mais candidaturas presidenciais no período.

Figura 2

Ideologia programática (V.Ideo) de candidaturas presidenciais na América Latina, por país, partido e ano da eleição (1998-2015)
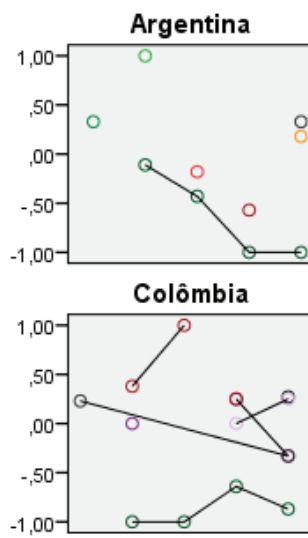

México

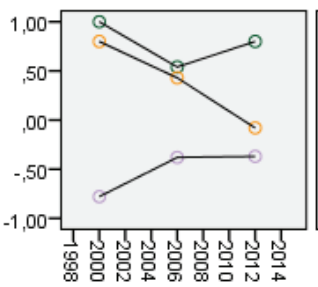

Bolívia

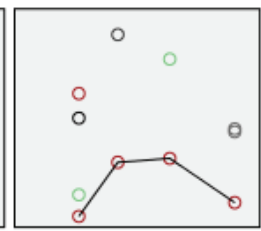

Costa Rica

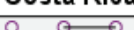

O O

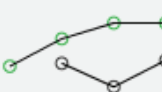

O

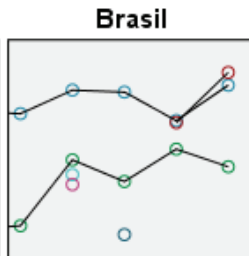

El Salvador
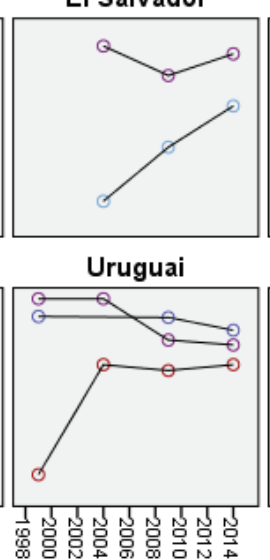

Chile

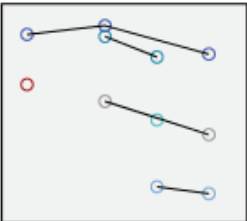

Equador

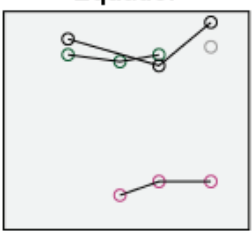

Venezuela

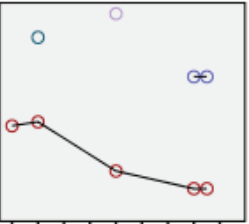

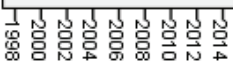

Fonte: Elaboração própria a partir de dados disponíveis em Oliveira (2016).

Considerando os fins desta pesquisa, duas considerações merecem destaque a partir das trajetórias desenhadas pelos partidos em suas mudanças ideológicas. A primeira diz respeito à observação de efetiva diversidade ideológica nas candidaturas presidenciais considera- 
das no conjunto dos países analisados. A partir do V.Ideo, revela-se que os países possuíram candidaturas presidenciais com programas de governo situados tanto no campo ideológico da esquerda quanto no da direita. A segunda observação diz respeito à manutenção dos partidos nos pleitos presidenciais. Com exceção de El Salvador, México e Uruguai, todos os outros países apresentam candidaturas presidenciais conjunturais, em apenas uma ocasião no período analisado, ou de maneira intermitente entre os pleitos. Na Argentina, na Bolívia e na Venezuela, o campo ideológico de direita foi ocupado em cada eleição por novas formações partidárias.

Finalmente, cabem algumas colocações sobre a utilização dos programas de governo lançados nas campanhas eleitorais presidenciais como fonte para identificar a ideologia programática dos partidos políticos. Tanto o momento eleitoral, em que a busca de votos é um objetivo premente, quanto a formação de alianças com outros partidos, são circunstâncias que condicionam e tendem a estressar as preferências ideológicas dos membros e líderes das organizações partidárias. A eleição presidencial força as agremiações a lidar não apenas com o público interno (militantes, membros, lideranças regionais e nacionais), mas também com o público externo (eleitorado em sentido amplo), vis-à-vis o posicionamento de seus contentores, os outros partidos e candidatos que participam do pleito. Portanto, o programa de governo das candidaturas presidenciais é uma aproximação das ideias e intenções políticas de uma organização partidária que opera sob as regras competitivas da democracia eleitoral. Neste sentido, oferece uma base empírica para a análise da ideologia tal qual se apresenta do partido, como unidade organizacional, para o exterior.

\section{COMPLEXIDADE ORGANIZACIONAL E IDEOLOGIA PROGRAMÁTICA NOS PARTIDOS LATINO-AMERICANOS}

A hipótese de Michels sobre a relação entre os aspectos organizativos dos partidos e seus valores ideológicos, resumida na lei de ferro da oligarquia, propõe que quando uma agremiação envelhece e cresce ela é levada por seus líderes a abandonar as proposições iniciais em favor de objetivos políticos mais moderados ou conservadores. Essa leitura da hipótese de Michels conecta a desideologização dos partidos a sua configuração organizacional interna. Uma questão em aberto, contudo, diz respeito à gravidade deste processo. Adotando como pressuposto uma relação linear entre complexidade da organi- 
zação e desideologização, três tendências podem ser inferidas, conforme as figuras abaixo.

Figura 3

Tendências de desideologização em partidos de esquerda

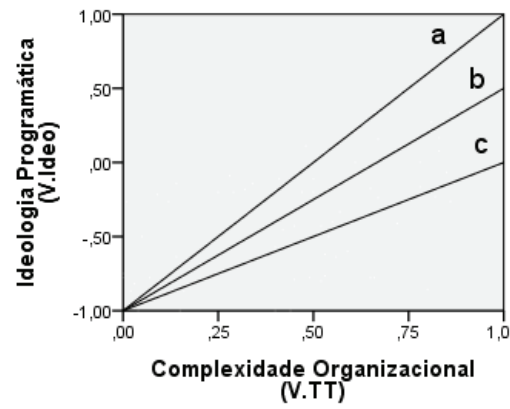

Fonte: Elaboração própria a partir de dados disponíveis em Oliveira (2016).
Figura 4

Tendências de desideologização em partidos de direita

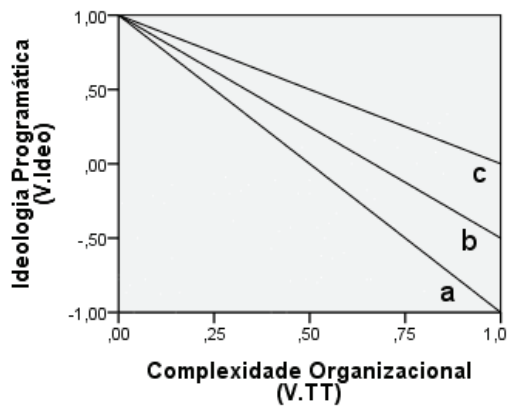

Fonte: Elaboração própria a partir de dados disponíveis em Oliveira (2016).

Na tendência mais grave ("a"), a expectativa implícita é pouco intuitiva, de que os partidos adotariam a versão mais radical da ideologia oposta à inicialmente adotada: no limite, partidos de extrema esquerda se tornariam partidos de extrema direita, e vice-versa. $\mathrm{Na}$ tendência intermediária (" $b$ "), a expectativa é a de que o desenvolvimento da complexidade organizacional tenderia a levar a agremiação a uma ideologia moderada no campo oposto ao adotado originalmente. Partidos de esquerda se tornariam partidos de centro-direita, partidos de direita se tornariam partidos de centro-esquerda. Por fim, a tendência mais branda da lei de ferro da oligarquia (" $c$ ") propõe como resultado da desideologização a adoção de uma posição ideológica de centro, ou seja, tanto partidos de direita quanto de esquerda tenderiam a se tornar partidos de centro.

Para tratar da desideologização dos partidos políticos, um passo inicial é identificar o campo ideológico das agremiações no contexto partidário da América Latina. A partir da variável indicadora da ideologia programática (V.Ideo), foram considerados como pertencentes ao campo de esquerda todas as agremiações cuja primeira observação na pesquisa encontra-se com valor negativo ou zero. Ou seja, que originalmente pertenciam ao campo da esquerda, mesmo que em eleições posteriores tenham migrado para o campo da direita. Os partidos cuja primeira observação do V.Ideo foi positiva foram considerados como 
pertencentes originalmente ao campo de direita. Excepcionalmente, foram considerados como originalmente de esquerda os partidos da Concertação de Partidos pela Democracia no Chile - o Partido Democrata Cristão (PDC), o Partido pela Democracia (PPD) e o Partido Socialista (PS), que ocuparam esta posição na perspectiva nacional.

A partir da hipótese de Michels, espera-se que as agremiações de esquerda e de direita que possuem maior complexidade apresentem programas de governo nas eleições presidenciais mais moderados do que aquelas recentes e menores. Radicalismo ideológico, no contexto desta pesquisa, é apreendido quando a V.Ideo localiza-se próxima aos valores máximos, de " 1 " (radical de direita) e "- 1 " (radical de esquerda). Moderação ideológica, por outro lado, percebe-se pela constatação de programas de governo que equilibram proposições de esquerda e direita, com V.Ideo próxima ao zero.

A Figura 5 apresenta a dispersão dos 127 casos de programa de governo presidenciais entre o eixo de complexidade organizacional do partido do candidato (V.TT) e o eixo de posicionamento ideológico esquerda/direita (V.Ideo) do respectivo programa.

\section{Figura 5}

Dispersão dos programas de governo presidenciais, por grupo ideológico original do partido do candidato, complexidade organizacional e ideologia programática

(América Latina, 1998-2015)

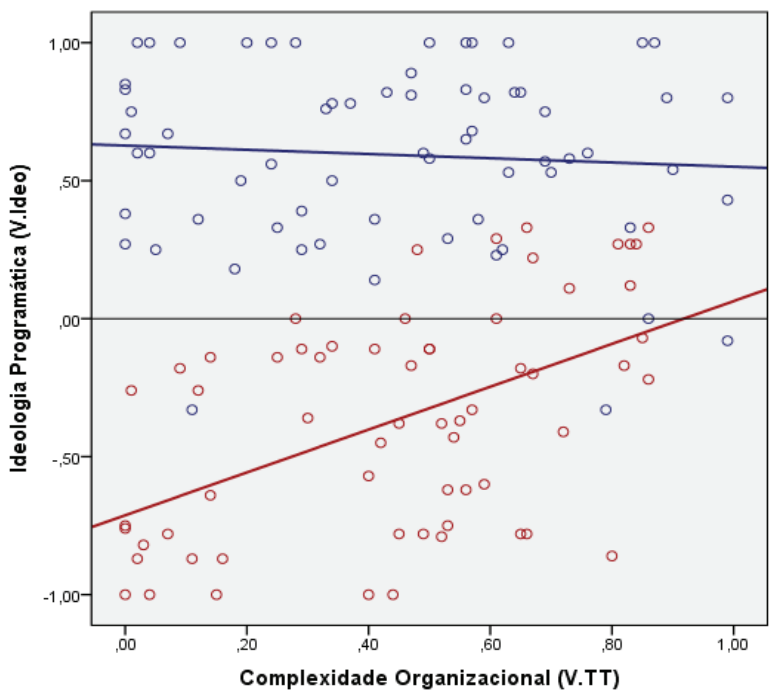

$$
\begin{gathered}
\text { Grupos de Ideologia } \\
\text { Original } \\
\text { Esquerda } \\
\text { Direita } \\
\text { Esquerda } \\
\text { Direita } \\
\begin{array}{c}
\text { Esquerda: } R^{2} \text { Linear }=0,255 \\
\text { Direita: } R^{2} \text { Linear }=0,005
\end{array}
\end{gathered}
$$


Os conjuntos de partidos orginalmente de direita e de esquerda mostram tendências diferentes. Dentre as agremiações consideradas como originalmente de direita, não há correlação significativa entre a complexidade organizacional das agremiações e a posição ideológica de seus programas de governo. Por outro lado, o conjunto de agremiações originalmente de esquerda mostra-se aderente à hipótese de Michels. Existe correspondência entre a complexidade organizacional das agremiações de esquerda e a ideologia programática que apresentam em suas candidaturas presidenciais, em sentido que coaduna com a lei de ferro da oligarquia. Ressalva-se que a exclusão dos partidos chilenos que compunham a Concertação de Partidos pela Democracia no Chile não altera de maneira relevante a correlação entre as variáveis (com ligeira queda no coeficiente de Pearson, de para 0,25 para 0,22 ).

\section{Figura 6}

Dispersão dos programas de governo presidenciais dos partidos originalmente de esquerda, por complexidade organizacional dos partidos políticos patrocinadores e ideologia programática (América Latina, 1998-2015)

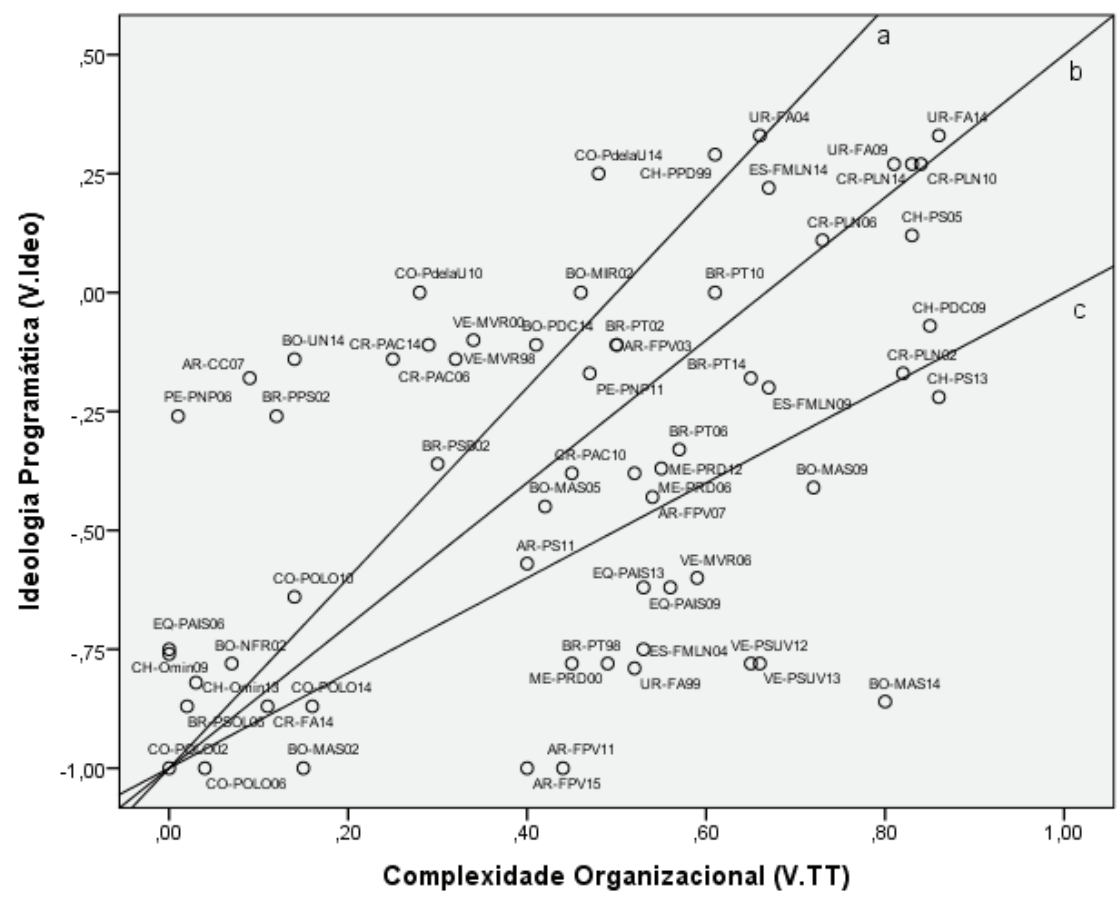




$\begin{array}{lll}\text { Legenda: } & \text { CR: Costa Rica } & \text { EQ: Equador } \\ \text { AR: Argentina } & \text { FA: Frente Amplo } & \text { PAIS: Aliança Pátria Altiva e } \\ \text { CC: Coalizão Cívica } & \text { PAC: Partido Ação Cidadã } & \text { Soberana } \\ \text { FPV: Frente Para a Vitória } & \text { PLN: Partido Liberação } & \text { ES: El Salvador } \\ \text { PS: Partido Socialista } & \text { Nacional } & \text { FMLN: Frente Farabundo } \\ \text { CH: Chile } & \text { BO: Bolívia } & \text { Martí de Libertação Nacional } \\ \text { PDC: Partido Democrata } & \text { MAS: Movimento ao } & \\ \text { Cristão } & \text { Socialismo } & \text { ME: México } \\ \text { PPD: Partido pela } & \text { NFR: Nova Força } & \text { PRD: Partido da Revolução } \\ \text { Democracia } & \text { Republicana } & \text { Democrática } \\ \text { Omin: Marco Enríquez- } & \text { UN: Unidade Nacional } & \text { PE: Peru } \\ \text { Ominami e Partido } & \text { PDC: Partido Democrata } & \text { PNP: Partido Nacional } \\ \text { Progressista } & \text { Cristão } & \text { Peruano } \\ \text { PS: Partido Socialista } & \text { BR: Brasil } & \text { UR: Uruguai } \\ \text { CO: Colômbia } & \text { PPS: Partido Popular } & \text { FA: Frente Amplo } \\ \text { PdelaU: Partido Social de } & \text { Socialista } & \text { VE: Venezuela } \\ \text { Unidade Nacional } & \text { PSB: Partido Socialista } & \text { MVR: Movimento Quinta } \\ \text { POLO: Polo Democrático } & \text { Brasileiro } & \text { República } \\ \text { Alternativo } & \text { PSOL: Partido Socialismo e } & \text { PSUV: Partido Socialista } \\ & \text { Liberdade } & \text { Unificado da Venezuela } \\ & \text { PT: Partido dos } & \end{array}$

Fonte: Elaboração própria. Cada caso é identificado pela sigla do país, seguida pela sigla do partido e o ano em que ocorreu a eleição presidencial a que se refere o programa de governo.

A Figura 6 apresenta a dispersão dos 62 casos de programas de governo presidenciais patrocinados por partidos políticos originalmente de esquerda. Apresenta, ainda, o código do país, o código do partido político e a referência do ano da eleição presidencial.

A percepção de aderência do comportamento dos partidos de esquerda à hipótese de Michels é favorecida pelos casos compreendidos entre as linhas "a" e " $c$ ". Já os programas de governo que se afastam deste campo denotam casos que a contraditam. Pode ser identificado um conjunto de 22 partidos com desvio significativo em relação à previsão da lei de ferro (35\% dos analisados). Seis programas (10\%) apresentam um desvio pouco relevante e 34 (54\%) coerentes com sua previsão.

Dentre os coerentes, foram consideradas as 11 candidaturas com programa de governo com ideologia enfática de esquerda e defendidas por partidos com baixa complexidade organizacional que ocupam o quadrante inferior esquerdo da Figura 6. Elas referem-se majoritariamente a quatro agremiações que permaneceram com uma posição 
marginal no sistema político. São eles o Polo Democrático Alternativo (POLO), da Colômbia, o Partido Progressista, considerando em conjunto com a primeira candidatura de Marco Enríquez-Ominami (Omin), no Chile, e os programas analisados do PSOL (Partido Socialismo e Liberdade) brasileiro e FA (Frente Ampla) da Costa Rica. Com exceção do POLO, essas experiências refletem novas agremiações que dissentem dos partidos de esquerda ou centro-esquerda mais tradicionais, adotando uma ideologia programática mais claramente à esquerda.

Três de seis programas de governo com desvios marginais da previsão da lei de ferro foram apresentados por candidatos de partidos que compõem a Concertação pela Democracia do Chile - PDC, PS e PPD. Eles mantiveram programas próximos do centro ideológico nas primeiras três candidaturas analisadas, de 1999 até 2009. Após a derrota nesta última eleição, contudo, a nova candidatura da coalizão, em 2013, capitaneada pelo PS, apresentou uma ideologia programática de centro-esquerda. Esta última mudança apresenta um leve desvio da previsão da lei de ferro, por ser mais à esquerda do que o previsto.

Um grupo de quatro programas de governo defendidos por partidos com baixa complexidade organizacional localiza-se ideologicamente em posições mais moderadas do que o esperado (centro-esquerda). Todos estes programas referem-se à primeira candidatura presidencial das agremiações. O Partido Nacional Peruano (PNP), em 2006, apresentou programa de centro-esquerda. Contudo, no contexto nacional, esta candidatura situa-se claramente à esquerda dos demais competidores. A Coalizão Cívica (CC) da Argentina, em 2007, e a Unidade Nacional (UN) da Bolívia, em 2014, apresentaram programas mais próximos do centro e, no contexto nacional, à direita dos principais competidores. Na eleição presidencial brasileira de 2002 o Partido Popular Socialista (PPS) também apresentou uma candidatura mais moderada do que permitiria supor a baixa complexidade organizacional da agremiação. Esses partidos não apresentaram outras candidaturas presidenciais no período, com exceção do PNP, que na eleição seguinte - em 2011 - figura no campo de coerência com a lei de ferro.

Outras seis candidaturas também destoam da lei de ferro das oligarquias por serem mais moderadas do que sua baixa complexidade organizacional preveria, mas em menor medida. Entre elas se encontram duas candidaturas do Partido Ação Cidadã (PAC), da Costa 
Rica, duas candidaturas patrocinadas pelo Partido Social de Unidade Nacional (PdelaU), da Colômbia, e a candidatura de 2014 do Partido Democrata Cristão (PDC), da Bolívia. Ao lado destas candidaturas que poderiam ser identificadas como de centro, chama atenção a presença das primeiras duas candidaturas do Movimento V República (MVR) da Venezuela, em 1998 e 2000, antes da fusão no Partido Socialista Unificado da Venezuela (PSUV).

Doze programas de governo ideologicamente de esquerda encontram-se em situação inversa, ou seja, são mais radicais do que o previsto por uma complexidade organizacional mais elevada. Este conjunto engloba candidaturas de esquerda em desconformidade com a lei de ferro, apresentadas pela Frente Para a Vitória (FPV) da Argentina, em 2011 e 2015; pelos venezuelanos MVR e seu sucessor PSUV em 2006, 2012 e 2013; pelas últimas duas candidaturas da equatoriana Aliança Pátria Altiva e Soberana (PAIS), de 2009 e 2013; e pela candidatura do Movimento ao Socialismo (MAS) da Bolívia, de 2014. Em 2009 o MAS também havia apresentado uma candidatura destoante, mas dentro do campo de centro-esquerda. Três destas agremiações, FPV, MAS e PAIS, apresentaram programas anteriores compatíveis com os parâmetros da lei de ferro, e o MVR - como já observado - mostrava programas mais moderados. Suas trajetórias, contudo, desviaram-se do comportamento previsto, pois índices mais elevados de complexidade organizacional não foram acompanhados por programas de governo ideologicamente posicionados próximos ao centro ideológico. Eles persistiram com uma ideologia de esquerda.

Ainda neste conjunto, quatro programas foram defendidos por partidos com experiências de candidaturas presidenciais anteriores, não compreendidas na pesquisa. São eles: o Partido dos Trabalhadores (PT) do Brasil, em 1998; a Frente Ampla (FA) do Uruguai, em 1999; o Partido da Revolução Democrática (PRD) do México, em 2000; e a Frente Farabundo Martí de Libertação Nacional (FMLN), de El Salvador, em 2004. Estes quatro partidos passaram, nas eleições seguintes, a apresentar programas de governo mais moderados e compreendidos na previsão da lei de ferro. Com exceção do PRD, eles conquistaram as cadeiras presidenciais de seus países no período pesquisado.

Em síntese, do conjunto de dados apresentados pode ser apreendida uma tendência principal de ajuste à lei de ferro da oligarquia, presente em três diferentes grupos. Um grupo de partidos que no período 
de análise ganharam complexidade organizacional e tornam-se mais moderados ideologicamente - PT, FA (Uruguai), FMLN, PRD. Aqueles que já se localizavam entre aqueles com elevada complexidade organizacional e ideologia programática moderada - PS (Chile), PPD, PDC, PLN. Por fim, o grupo de partidos que se manteve com baixa complexidade organizacional e ideologia programática radical, de esquerda - POLO, PRO, PSOL, FA (Costa Rica). Estes grupos compreendem os principais partidos de esquerda do Brasil, Uruguai, México, El Salvador, Chile e Costa Rica. Um conjunto menos expressivo de partidos, contudo, apresenta experiências que não coadunam com a lei de ferro. Destacam-se o FPV, MVR/PSUV, MAS e PAIS, que mantiveram ou adotaram uma ideologia programática radical independente de alterações na complexidade organizacional. Trata-se das principais alternativas partidárias no campo da esquerda de Argentina, Venezuela, Bolívia e Equador, respectivamente, e todos os partidos de presidentes eleitos na primeira ou segunda (Bolívia) eleição disputada.

\section{DISCUSSÃO: TRAJETÓRIAS DE ADESÃO E DIVERGÊNCIA DA LEI DE FERRO DA OLIGARQUIA}

Segundo a hipótese de Michels, os partidos estariam propensos a abandonar seus princípios ideológicos na medida em que crescem e envelhecem, tornando-se mais moderados ou conservadores. Esta abordagem da lei de ferro da oligarquia, enquanto desideologização, revelou-se capaz de lançar luz sobre a diferença ideológica percebida entre os partidos de esquerda na América Latina. Além do conjunto de casos isolados (candidaturas presidenciais), foram capturadas na pesquisa algumas trajetórias partidárias de mudança organizacional e programática. A aproximação desses exemplos pode ajudar a apreender quais circunstâncias favorecem, e quais bloqueiam, a ocorrência do fenômeno apreendido pela lei de ferro.

Em um período restrito de tempo, de 15 anos, foi possível visualizar quatro partidos no momento em que operaram relevantes transformações em suas ideologias programáticas: o PT, no Brasil, a FA, do Uruguai, a FMLN, de El Salvador e, em menor medida, o PRD, do México. Após atingirem um grau intermediário de complexidade organizacional, estes partidos mudaram ideologicamente e abandonaram os programas de governo no campo de esquerda em favor de uma posição mais moderada ou mesmo de direita (Figura 7). Com 
estas transformações, esses partidos adequaram-se ao predito pela lei de ferro da oligarquia. Contudo, a trajetória de mudança programática não foi incremental ou proporcional ao aumento da complexidade organizacional. Ela ocorreu abruptamente em 2002 no PT, em 2004 pra FA, em 2006 para o PRD e em 2009 na FMLN.

A trajetória de outros quatro partidos de esquerda apresentaram um comportamento antagônico à previsão da lei de ferro. O MVR, sucedido pelo PSUV, na Venezuela; o MAS, na Bolívia; o FPV, na Argentina; e o PAIS, no Equador, mantiveram uma ideologia radical de esquerda ou a adotaram independente da complexidade organizacional de suas agremiações (Figura 8). Nota-se, ainda, que estas quatro agremiações alcançaram índices de complexidade (V.TT) semelhantes aos do grupo que aderiu à lei de ferro (PT, FA, FMLN e PRD).

Figura 7

Complexidade organizacional e ideologia em partidos selecionados (PT,

FMLN, FA, PRD), por ano de eleição presidencial (América Latina, 1989-2014)

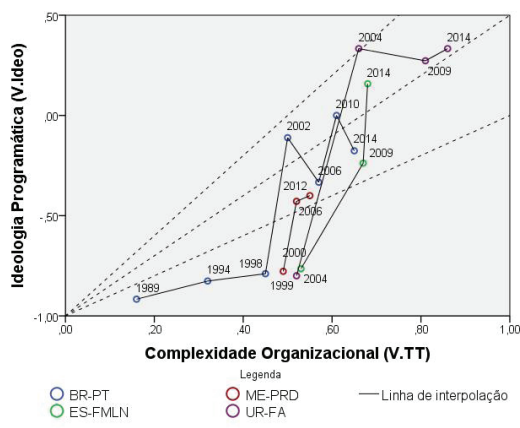

Fonte: Elaboração própria a partir de dados disponíveis em Oliveira (2016).

\section{Figura 8}

Complexidade organizacional e ideologia em partidos selecionados (FPV, PAIS, MAS, MVR/PSUV), por ano de eleição presidencial (América Latina, 1998-2014)

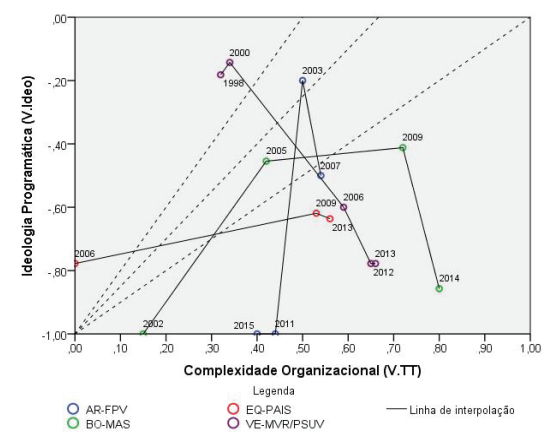

Fonte: Elaboração própria a partir de dados disponíveis em Oliveira (2016).

Como a lei de ferro pode ser reinterpretada a partir destas observações empíricas? De acordo com a abordagem de Lipset (2010), o sentido da hipótese de Michels poderia ser revisto como a busca da sobrevivência dos líderes organizacionais em ambientes competitivos, e não simplesmente como uma tendência conservadora ${ }^{7}$. A implicação é a inclusão de um elemento estratégico, sob controle dos líderes partidários, que condiciona a desideologização. Apreende, também, a possibilidade de (re)radicalização ideológica quando esta torna-se uma estratégia útil para os líderes partidários. 
Uma diferença circunstancial importante entre os dois grupos de partidos anteriormente ressaltados diz respeito ao momento em que capturaram a cadeira presidencial em seus países. FPV, MVR e PAIS conseguiram capturá-las nas primeiras eleições que disputaram. $\mathrm{O}$ MAS, em sua segunda tentativa. Ao contrário, os partidos em que se observou uma trajetória com adesão à lei de ferro possuem uma história mais dilatada de disputas antes de elegerem o presidente de seus países (PT, FA e FMLN), ou, no caso do PRD, não o elegeu. É possível, portanto, que fatores estratégicos sobre as condições de vencer as eleições presidenciais condicionem a mudança ideológica.

Também podem surgir incentivos de fora do ambiente eleitoral. Entre os casos estudados, a trajetória do MVR venezuelano é a que mais claramente contradiz a lei de ferro da oligarquia. Ela é marcada por um acontecimento que parece relevante. Após a segunda eleição do presidente Hugo Chávez ocorreu, em 2002, um golpe de Estado que afastou temporariamente Hugo Chávez da Presidência venezuelana. Não é possível discernir em que medida o golpe de Estado malsucedido está imbricado com a posterior radicalização programática do MVR. Pode-se esperar, contudo, que um acontecimento que coloca em risco a existência do partido possua profundos efeitos organizacionais.

Estas breves inferências evidenciam que outros fatores operam sobre o posicionamento e a mudança ideológica dos partidos políticos latino-americanos, para além dos incentivos apreendidos da complexidade organizacional. Foge do escopo da pesquisa escrutinar sob quais conjunturas organizacionais internas a desideologização torna-se mais provável. Ou, ainda, avançar sobre fatores contextuais, como as disputas ideológicas nos sistemas partidários nacionais e os choques provenientes do ambiente. O que se torna necessário é um esforço que vise compatibilizar a lei de ferro da oligarquia com as transformações ideológicas apreendidas na pesquisa.

Nesse sentido pode-se fazer a proposição de que diferentes níveis de complexidade possuem efeitos mais ou menos fortes, mais ou menos autônomos, sobre outros aspectos da vida organizacional ou, no caso em tela, sobre a ideologia programática ${ }^{8}$. Para averiguar esta possibilidade recorre-se a uma regressão local que escreve a relação entre as variáveis de estudo sem a suposição de lineariedade, permitindo que "os dados falem por si próprios" (Marquetti e Viali, 2004). O resultado, exibido na Figura 9, mostra uma relação seccionada em três 
momentos. Em uma etapa intermediária, entre os pontos "a" e " $b$ ", a ideologia programática deixa de responder positivamente ao aumento da complexidade organizacional. Este é o efeito dos casos que desviam da lei de ferro sobre o conjunto de casos investigado.

Figura 9

Dispersão dos programas de governo presidenciais dos partidos originalmente de esquerda, por complexidade organizacional dos partidos políticos patrocinadores e ideologia programática, com linha de regressão local (América Latina, 1998-2015)

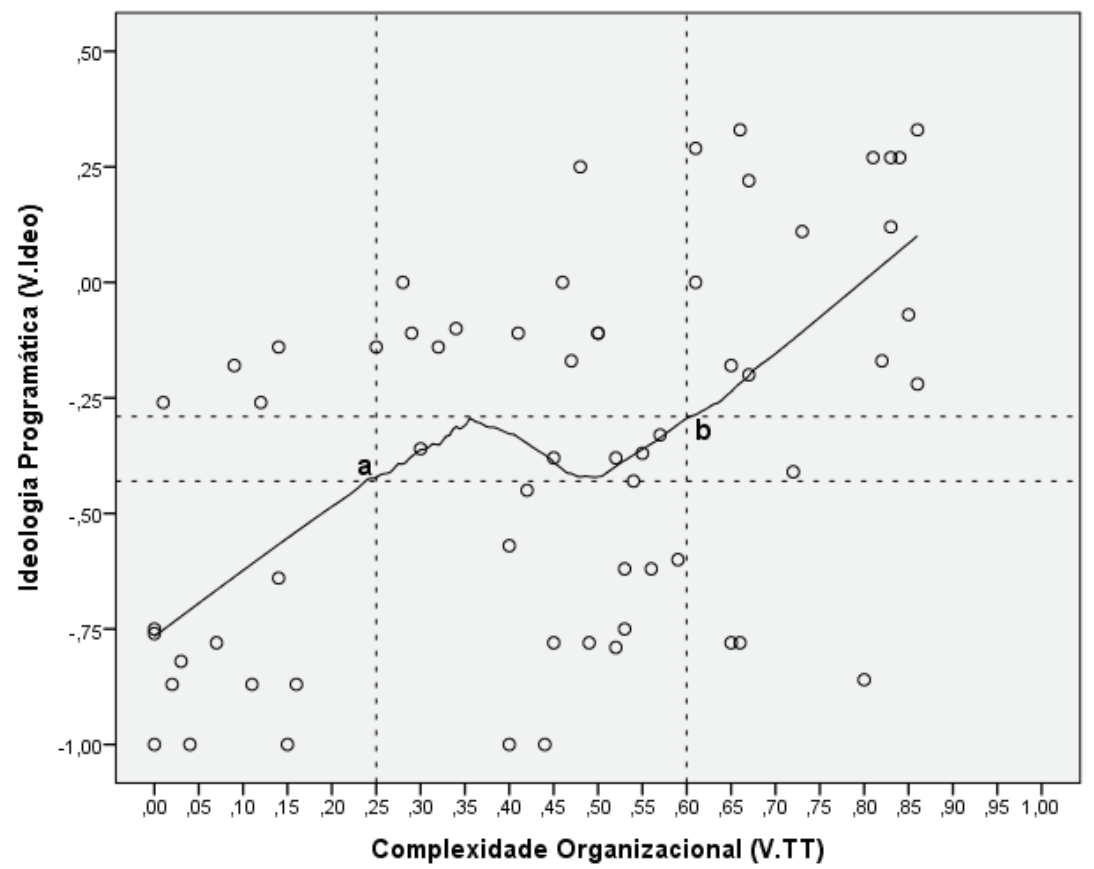

Fonte: Elaboração própria a partir de dados disponíveis em Oliveira (2016).

Após o hiato de transição (ponto "b") os partidos que apresentam elevada complexidade organizacional e programas de governo moderados parecem ter consolidado sua posição ideológica. Na pesquisa, não foi observado nenhum caso de partido que, tendo atingido estas condições, passasse posteriormente a apresentar um programa de governo no campo de esquerda.

O caso de radicalização mais relevante, dentre os partidos que ultrapassaram o limite de transição " $b$ ", é o do PS chileno. O partido apresentou nas eleições de 2013 um programa de governo marginalmente fora da premissa de desideologização da lei de ferro da oligarquia (contudo, ainda dentro da centro-esquerda). Fatores externos podem 
ter influenciado o partido neste movimento: derrota da candidatura à Presidência da Concertação de Partidos pela Democracia em 2009 (choque externo); pressão ideológica de uma candidatura e de um novo partido de esquerda eleitoralmente viável (Marco Enríquez-Ominami e Partido Progressista) ${ }^{9}$; campo ideológico da direita ocupado por agremiações tradicionais. O caso do PS chileno indica que mesmo partidos com elevada complexidade organizacional e que já promoveram transformações no sentido da moderação programática podem voltar a exibir programas de governo sensivelmente mais à esquerda (e fora da predição da lei de ferro). Contudo, foram necessários incentivos externos importantes para que uma mudança ideológica relativamente pequena ocorresse.

Como regra, pode-se apreender que a opção pela desideologização é uma estratégia que se torna viável para os líderes partidários em organizações que atingem um grau intermediário de complexidade organizacional, mas que pode ser evitada caso existam incentivos contrários provenientes do ambiente externo. Entre os partidos que adotam uma ideologia moderada e alcançam níveis elevados de complexidade organizacional, a liberdade para um processo de (re)radicalização parece ser reduzida. Portanto, a análise valida a existência de uma lei, se não férrea, bastante dura sobre a perda do radicalismo ideológico dos partidos que adotam a estratégia de desideologização a partir de um ponto de elevada complexidade organizacional. Este ponto é dado, empiricamente, pela V.TT na casa de $60 \%$ de sua amplitude.

Fatores externos também podem explicar por que os partidos de direita não são eivados pela lei de ferro da oligarquia. Poder-se-ia esperar que os efeitos ideológicos provenientes da tendência de aumento da complexidade organizacional (desideologização) fossem semelhantes entre os grupos de esquerda e de direita, caso fossem neutros a este respeito os mecanismos do processo de oligarquização. Dado o fato de que divergem as tendências percebidas entre os partidos de esquerda e de direita na América Latina, se a lei de ferro possui alguma validade para os partidos de esquerda, deve-se investigar o motivo pelo qual seus mecanismos tornam-se inoperantes em face dos partidos de direita. Segue uma proposição provisória sobre esta questão, novamente baseada nos efeitos contrários de ambientes competitivos sobre a lei de ferro. 
Anteriormente, destacou-se como a competição partidária em um mercado eleitoral aberto pode influenciar a (re)radicalização. Santos expõe outro limite da lei de ferro: quando é o sistema partidário que sofre a competição, nas formas de participação, com organizações próprias da sociedade: "a lei de ferro da oligarquia foi e é verdadeira em contextos nos quais o oligopólio da oferta de participação puder ser mantido pelo sistema partidário" (Santos, 1988:141). Na reinterpretação do argumento de Marenco e Noll (2012), esta espécie de competição a qual o sistema partidário pode ser submetido implicaria maior responsabilização dos representantes frente aos representados. A inferência, aqui, é de que os grupos sociais afeitos ao campo de direita (neoliberalismo) possuem suficiente autonomia do sistema partidário na América Latina para contornar a representação partidária. $\mathrm{O}$ conjunto de partidos de direita se torna imune à lei de ferro, nesta perspectiva, pois a desideologização deixa de ser uma possibilidade estrategicamente viável para constituir uma ameaça à permanência da organização.

\section{CONSIDERAÇÕES FINAIS}

Quando Michels propôs a lei de ferro da oligarquia, surgia uma das mais persistentes críticas à intermediação dos partidos políticos, senão à própria representação democrática. Nos mais de cem anos que se passaram, muitos autores buscaram contrapor seus argumentos e restringir sua validade. A começar pelo próprio Michels que, na segunda edição de seu livro, imprimiu uma versão tendencial da relação entre organização e oligarquia (Ribeiro, 2012:42). Buscou-se apresentar, neste artigo, uma aplicação da lei de ferro para os partidos da América Latina contemporânea focada no viés da desideologização. Os aspectos ideológicos dos partidos foram resumidos a sua dimensão econômica e, exclusivamente, de acordo com os programas de governo lançados em candidaturas presidenciais. Outro limite analítico surge ao utilizar como indicadores de complexidade organizacional a idade e o número/proporção de representantes da agremiação na câmara baixa.

Dentro desta moldura, foi possível investigar um fenômeno que tem sido difícil de mensurar com objetividade. A relação entre organização e ideologia mostrou-se capaz de iluminar parcialmente as diferenciações políticas operadas pelas agremiações partidárias de esquerda ${ }^{10}$. Partidos de esquerda com maior complexidade organiza- 
cional efetivamente tendem a apresentar programas de governo mais conservadores. Contudo, elementos exteriores à lei de ferro influenciam a existência de desideologização. Antes do que mudanças ideológicas incrementais, os partidos cujo momento de desideologização foi capturado na pesquisa realizaram saltos ideológicos. Isso denota a existência de elementos estratégicos em uma decisão pela mudança programática.

Sobretudo no período inicial das organizações, a ocasião das vitórias em candidaturas presidenciais e o contexto político nacional parecem elementos relevantes para que a lei de ferro torne-se operante. Partidos que enfrentaram sucessivas eleições presidenciais e alcançaram níveis intermediários de complexidade organizacional sem alcançar a vitória (PT, FMLN, FA e PRD) aderiram a programas de governo moderados. Partidos que conquistaram a cadeira presidencial em suas primeiras tentativas (MVR, FPV, MAS, PAIS), mesmo quando avançaram em complexidade organizacional, não fixaram uma tendência de desideologização e, em alguns casos, passaram a adotar programas de governo mais radicais enquanto ocupavam a Presidência de seus países. Em favor da apreensão de Michels, parece existir um ponto de "não retorno" da desideologização. Durante o período de pesquisa, nenhum partido de esquerda que apresentou elevada consolidação organizacional e ideologia programática moderada, dentro da previsão da lei de ferro, passou a apresentar subsequentemente programas de esquerda. Chega-se, assim, à apreensão da validade parcial da lei de ferro enquanto desideologização no contexto da América Latina contemporânea. 


\section{Augusto Neftali Corte de Oliveira}

\section{NOTAS}

1. O principal limite é a obtenção de programas de governo das candidaturas presidenciais. Outro limite diz respeito ao número de programas analisados em cada eleição. Buscou-se incluir em cada pleito nacional os programas de governo das principais candidaturas em volume de votos, compreendendo ao menos $70 \%$ do sufrágio. Em seis eleições, contudo, não foi possível alcançar este número: na Argentina em 1999 e 2003, na Colômbia em 1998, no Equador em 2002 e 2006 e na Venezuela em 1998. Nestes casos, foram considerados na investigação apenas o principal ou os dois principais partidos competidores.

2. Compõe a explicação de Michels um componente psicológico da diferenciação entre chefes e massa. Este elemento da lei de ferro da oligarquia não é considerado na presente pesquisa, que se limita aos aspectos organizacionais.

3. Após o trabalho de Lipset e colegas, pesquisas de survey sobre opiniões e valores presentes entre os membros da base das organizações e suas lideranças tornaram-se a forma usual para testar a existência de oligarquização como falta de responsividade. Exemplos e sugestões podem ser encontrados em Rohrschneider (1994), Madsen (1996) e Ribeiro (2014).

4. Segundo Ribeiro (2012), as breves inferências que associam a lei de ferro a aspectos ambientais e à competição partidária não elidem o desprezo de Michels, na abordagem em questão, aos aspectos externos à organização partidária (o que, segundo Ribeiro, constitui uma das fragilidades da obra).

5. Para uma leitura que relaciona o trabalho de Panebianco no contexto das proposições de Michels e seus críticos, ver Braga (2012).

6. A dicotomia esquerda/direita em termos de uma distinção especificamente econômica, está, há um longo período, exposta à superação ou concorrência por distinções pósmaterialistas. A interpretação adotada na pesquisa justifica-se, ao menos, por três argumentos. Embora já expresse uma defasagem impressionante em relação ao que Michels propõe como objetivos ideológicos primários dos partidos socialistas, a temática econômica parece mais condizente com o quadro geral de análise do que a abordagem pós-materialista. Na América Latina recente, a questão econômica da contraposição entre o neoliberalismo e sua alternativa é indicada como um aspecto central da disputa política (Lora e Oliveira, 2005; Coutinho, 2006; Baker e Greene, 2011). Por fim, como ressaltam Castro e Capistrano (2008), as relações descritas como pósmateriais no Ocidente não encontram a mesma força na América Latina pós-neoliberal, o que indica a necessidade de repensar a tese neste contexto.

7. Michels (1982:234) tangenciou esta alternativa, ao admitir - como rara, sublinhe-se uma situação na qual a burocracia partidária contradisse o interesse da classe operária ao adotar políticas audaciosas ou agressivas.

8. Esta proposição é compatível com a noção de limite crítico de sobrevivência e de enrijecimento organizacional proposta por Panebianco (2005:374). O autor indica um ponto hipotético baixo da dimensão (tamanho), que força as lideranças a lutarem pela sobrevivência da organização. E um ponto hipotético alto que, quando ultrapassado, importa em um nível de complexidade interna suficientemente elevado para retirar da 
liderança a capacidade de gestão. Entre estes limites, a dimensão da organização teria seus efeitos mediados pelas dinâmicas internas, como as disputas entre dirigentes.

9. Kitschelt (2000:168) explora o surgimento de novos partidos em parte de uma crítica à noção de desideologização como perda de responsividade. O autor aponta que, caso não responsiva para com um conjunto expressivo de eleitores, a mudança programática (desideologização) poderia favorecer a formação de novos partidos políticos que capturem os eleitores descontentes. Este mecanismo puniria e, no limite, impediria a desideologização não responsiva. Do conjunto de países em que esta circunstância pode ser observada (PSOL, Brasil; FA, Costa Rica; e PRO, Chile) apenas no caso chileno do PS verificou-se a subsequente radicalização do partido tradicional, o que pode ser apreendida como estratégia para bloquear a nova formação.

10. A presente pesquisa não avança sobre os mecanismos causais implicados nesta relação. Uma abordagem em profundidade dos casos que aderem e desviam-se do predito pela lei de ferro poderia oferecer mais informações sobre como as transformações organizacionais pressionam a ideologia dos partidos políticos. 


\section{REFERÊNCIAS BIBLIOGRÁFICAS}

BAKER, Andy; GREENE, Kenneth. (2011), “The Latin American left's mandate: free market policies and issue voting in new democracies". World Politics, 63(1), pp. 43-77.

BASEDAU, Matthias; STROH, Alexander. (2008), “Measuring party institutionalization in developing countries: a new research instrument applied to 28 african political Parties". Giga Working Paper, (68). Disponível em: https://www.giga-hamburg.de/de/ system/files/publications/wp69_basedau-stroh.pdf. Acesso em 17/05/2019.

BRAGA, Maria do Socorro Sousa. (2012), “Democracia e organização nos partidos políticos: revisando os microfundamentos de Michels". Revista de Sociologia e Política, 20(44), pp. 83-95.

BRUTON, Henry J. A. (1998), “Reconsideration of import substitution”. Journal of Economic Literature, 36(2), pp. 903-936.

CASSINELLI, Charles W. (1953), "The law of oligarchy". The american political science review, 47(3), pp. 773-784.

CASTRO, Henrique Carlos de Oliveira de; CAPISTRANO, Daniel. (2008), “Cultura política pós-consenso de Washington: o conceito de Cultura Cívica e a mudança política na América Latina". Revista Debates, 2(1), pp. 75-97.

COUTINHO, Marcelo. (2006), “Movimentos de mudança política na América do Sul contemporânea". Revista de Sociologia e Política, (27), pp. 107-123.

DOŠEK, Tomáš. (2016), "Party membership in Latin America party strategies and the role of party members". Taiwan Journal of Democracy, vol. 12, n 1, pp. 169-198.

DOWNS, Anthony. (1999), Uma teoria econômica da democracia. São Paulo, Edusp.

FONSECA, Pedro. (2004), “Gênese e precursores do desenvolvimentismo no Brasil”. Revista Pesquisa \& Debate, 15(2), pp. 225-256.

GROHMANN, Luís Gustavo Mello. (2001), “A separação de poderes em países presidencialistas: a América Latina em perspectiva comparada". Revista de Sociologia e Política, (17), pp. 75-106.

HANDS, Gordon. (1971), "Roberto Michels and the study of political parties". British Journal of Political Science, 1(2), pp. 155-172.

HARMEL, Robert; JANDA, Kenneth. (1994), "An integrated theory of party goals and party change". Journal of Theoretical Politics, (6), pp. 259-287.

KATZ, Richard S. MAIR, Peter. (1995), “Changing models of party organization and party democracy: the emergence of the Cartel Party". Party Politics, (1), pp. 5-28.

KIRCHHEIMER, Otto. (1980), "El Camino hacia el partido de todo el mundo", in K. LENK e F. NEUMANN (eds.), Teoría y sociología críticas de los partidos políticos. Barcelona: Anagrama, pp. 328-347

KITSCHELT, Herbert. (2000), “Citizens, politicians, and party cartellization: political representation and state failure in post-industrial democracies". European Journal of Political Research, (37), pp. 149-179. 
LEACH, Darcy. (2005), "The iron law of what again? Conceptualizing oligarchy across organizational forms". Sociological Theory, 23(3), pp. 312-337.

LIPSET, Seymour M. (2010), "Democracy in private government (a case study of the International Typographical Union)". The British Journal of Sociology, 61(1), pp. 9-27.

LIPSET, Seymour M.; ROKKAN, Stein. (1992), “Estruturas de clivagem, sistemas partidários e alinhamentos de eleitores", in $\mathrm{S}$. M. Lipset (ed.), Consenso e conflito: ensaios de sociologia política. Lisboa: Gradiva, pp. 161-259.

LORA, Eduardo; OLIVEIRA, Mauricio. (2005), "The electoral consequences of the Washington Consensus". Economia, 5(2), pp. 1-61.

LUCAS, João Inácio Pires. (2000) “A estabilidade dos dirigentes partidários do PMDB e PT no RS, 1979/1995". Cadernos de Ciência Política, (5), pp. 35-51.

MADSEN, Morten. (1996), "Trade union democracy and individualization: the case of Denmark and Sweden". Industrial Relations Journal, 27(2), pp. 115-128.

MARANGOS, John. (2009), "The Evolution of the term 'Washington Consensus'”. Journal of Economic Surveys, 23(2), pp. 350-384.

MARQUETTI, Adalmir; VIALI, Lorí. (2004), "Princípios e aplicações de regressão local". Revista Análise Econômica, ano 22, (42), pp. 253-277.

MARENCO, André. (2012), “Reformas eleitorais na América Latina: grandes expectativas, poucos casos, resultados perversos". Sociologias, ano 14, (31), pp. 238-268.

MARENCO, André; NOLL, Maria Izabel. (2012), “Décadas de Michels: marcos contextuais e prazo de validade para a lei de ferro". Revista de Sociologia e Política, 20(44), pp. 63-72.

MAY, John. (1965), "Democracy, organization, Michels". The American Political Science review, 59(2), pp. 417-429.

(1973), “Opinion structure of political parties: the special law of curvilinear disparity". Political Studies, 21(2), pp. 135-151.

MICHELS, Robert. (1982), Os partidos políticos. Brasília, UNB.

MIGUEL, Luis Felipe. (2014), “Oligarquia, democracia e representação no pensamento de Michels". Revista Brasileira de Ciência Política, (13), pp. 137-154.

OLIVEIRA, Augusto Neftali Corte de. (2015), “A ideologia econômica dos presidentes na América Latina: um indicador a partir dos programas de governo eleitorais". Indicadores Econômicos FEE, 43(1), pp. 83-98.

(2016). Banco de Asserções Programáticas. Disponível em https://www.fee. rs.gov.br/wp-content/uploads/2016/05/20160517bap.2015.xlsx

PANEBIANCO, Angelo. (2005), Modelos de partidos: organização e poder nos partidos políticos. São Paulo, Martins Fontes.

PRZEWORSKI, Adam. (1989), Capitalismo e social-democracia. São Paulo, Companhia das Letras.

PRZEWORSKI, Adam. (1994), Democracia e mercado: no Leste Europeu e na América Latina. Rio de Janeiro: Relume-Dumará. 


\section{Augusto Neftali Corte de Oliveira}

PRZEWORSKI, Adam; SPRAGUE, John. (1986), Paper stones: a history of electoral socialism. Chicago: University of Chicago.

RIBEIRO, Pedro Floriano. (2009), "Robert Michels e a oligarquia do Partido dos Trabalhadores". Teoria \& Pesquisa, vol. 18, pp. 119-150.

RIBEIRO, Pedro Floriano. (2012), "Realismo e utopia em Robert Michels". Revista de Sociologia e Política, 20(44), pp. 31-46.

. (2014), "A Lei de Ferro da Oligarquia de Michels: Modos de usar". Revista Brasileira de Ciência Política, 29(85), pp. 179-193.

RODRIK, Dani. (2006), “Goodbye Washington Consensus, hello Washington Confusion?”. Journal of Economic Literature, 44(4), pp. 973-987.

ROHRSCHNEIDER, Robert. (1994), "How iron is the iron law of oligarchy?". European Journal of Political Research, 25, pp. 207-238.

SÁEZ, Manuel Alcántara; FREIDENBERG, Flavia. (2001), “Organización y funcionamiento interno de los partidos políticos en América Latina", in M. SÁEZ e F. FREIDENBERG (eds.), Partidos Políticos de América Latina: Centroamérica, México y República Dominicana. Salamanca, Universidad de Salamanca.

SANTOS, Wanderlei Guilherme dos. (1988), Paradoxos do liberalismo. Rio de Janeiro: Iuperj, Vértice.

SCHONFELD, William R. (1980a), "La stabilité des dirigeants des partis politiques: le personnel des directions nationales du Parti socialiste et du mouvement gaulliste". Revue Française de Science Politique, 30(3), pp. 477-505.

. (1980b), “La stabilité des dirigeants des partis politiques: la théorie de l'oligarchie de Robert Michels". Revue Française de Science Politique, vol. 30, n 4, pp. 846-865.

STAUBER, Jakub. (2015), "Party institutionalization in the Czech Republic: towards a new measurement of the theoretical concept". Central European Political Studies Review, vol. $17, \mathrm{n}^{\circ} 3-4$, pp. 249-275.

STRØM, Kaare. (1990), "A behavioral theory of competitive political parties". American Journal of Political Science, 34(2), pp. 565-598.

ZOVATTO, Daniel. (2005), “Financiamento dos partidos e campanhas eleitorais na América Latina: uma análise comparada". Opinião Pública, 11(2), pp. 287-336. 


\section{APÊNDICE}

Anexo 1 - Asserções programáticas por política pública e ideologia

Comercial (esquerda)

Internacional: Imperialismo (Referência Internacional: Diminuir barreiras comerciais Negativa), anti-ALCA, anti-EUA (V.04); com outros países (Referência Positiva) Privatização (Referência Negativa): crítica, (V.03); Internacional: Diminuir barreiras reverter (V.13); Nacionalização (Referência comerciais com EUA, NAFTA, CAFTA, ALCA Positiva) (V.14); Economia: substituição de (Referência Positiva) (V.02); Privatização importações, protecionismo (Referência (Referência Positiva) (V.12); Participação Positiva) (V.61); Atuação em setores privada em setores estratégicos (mineração, estratégicos (mineração, energia, recursos energia, recursos) (Referência Positiva) (V.37); naturais) (Referência Positiva) (V.36).

\section{Regulação (esquerda)}

Regulação do mercado: funcionar melhor, Eficiência administrativa, eficiência do contra cartéis, monopólios (Referência governo, antiburocracia (pró-mercado) Positiva) (V.28); Regulação do mercado (Referência Positiva) (V.18); Regulação do trabalho: aumentar, proteção do trabalhador mercado trabalho: flexibilização relações, (Referência Positiva) (V.29); Regulação do livre negociação (Referência Positiva) (V.30); mercado trabalho: fiscalizar aplicação das Livre mercado - valor da política interna normas (Referência Positiva) (V.31); Regulação (Referência Positiva) (V.16); Propriedade, de setores estratégicos (mineração, energia, garantir (Referência Positiva) (V.22).

recursos naturais) (Referência Positiva) (V.35).

Fiscal (esquerda)

\section{Fiscal (direita)}

Tributos: mais progressivo, menos regressivo Tributos: diminuir sobre a produção/consumo (Referência Positiva)(V.07); Tributos:aumentar (mais investimento, emprego) (Referência sobre capital, riqueza, fortuna (Referência Positiva) (V.10); Tributos: diminuir sobre Positiva) (V.08); Tributos: fiscalização, combate o capital (mais investimento, emprego) à evasão (Referência Positiva) (V.09)

Financeira (esquerda) (Referência Positiva) (V.11)

\section{Financeira (direita)}

Regulação do mercado financeiro, capital, Mercado financeiro, bancos privados bancos (Referência Positiva) (V.32); Economia: (Referência Positiva) (V.34); Economia: auditoria, renegociação, revisão dos contratos pagamento da dívida, respeito aos contratos, (Referência Positiva) (V.53); Economia: cumprir obrigações (Referência Positiva) investimento externo direto (Referência (V.51); Economia: investimento externo direto Negativa) (V.58).
(Referência Positiva) (V.48). 


\begin{tabular}{|c|c|}
\hline Monetária e Gasto Público (esquerda) & Monetária e Gasto Público (direita) \\
\hline $\begin{array}{l}\text { Internacional: FMI, BM (Referência Negativa): } \\
\text { negativa, interromper relações (V.06); } \\
\text { Economia: crescimento baseado no mercado } \\
\text { interno (Referência Positiva) (V.59); Economia: } \\
\text { intervenção na taxa de câmbio (Referência } \\
\text { Positiva) (V.57); Economia: gasto público, } \\
\text { estímulo da demanda em crise (Referência } \\
\text { Positiva) (V.60); Socialismo (Referência } \\
\text { Positiva) (V.21); Neoliberalismo, liberalismo } \\
\text { (Referência Negativa) (V.17). }\end{array}$ & $\begin{array}{l}\text { Internacional: FMI, BM: manter ou aumentar } \\
\text { relações (Referência Positiva) (V.05); } \\
\text { Economia: autonomia do Banco Central } \\
\text { (Referência Positiva) (V.44); Economia: } \\
\text { controle da inflação meta da política } \\
\text { econômica (Referência Positiva) (V.43); } \\
\text { Economia: não intervenção na taxa de câmbio, } \\
\text { moeda forte (Referência Positiva) (V.47); } \\
\text { Economia: controle, diminuição do gasto } \\
\text { público (Referência Positiva) (V.50); Economia: } \\
\text { redução ou limitação do déficit orçamentário } \\
\text { (Referência Positiva) (V.41); Economia: } \\
\text { superavit orçamentário (Referência Positiva) } \\
\text { (V.42); Economia: corte/controle de gastos } \\
\text { públicos contra crise (Referência Positiva) } \\
\text { (V.45); Economia: poupança pública, reservas } \\
\text { internacionais (Referência Positiva) (V.46). }\end{array}$ \\
\hline Outras (esquerda) & Outras (direita) \\
\hline $\begin{array}{l}\text { Reforma agrária (Referência Positiva) } \\
\text { (V.70); Latifúndio (Referência Negativa) } \\
\text { (V.71); Planejamento econômico: função do } \\
\text { governo (Referência Positiva) (V.27); Saúde } \\
\text { - participação privada (Referência Negativa) } \\
\text { regulação, limitação (V.65) }\end{array}$ & $\begin{array}{l}\text { Saúde - participação privada (Referência } \\
\text { Positiva) (V.64); Educação - participação } \\
\text { privada (Referência Positiva) (V.66) }\end{array}$ \\
\hline
\end{tabular}




\section{RESUMO \\ Organização e Ideologia nos Partidos da América Latina: uma Aproximação da Hipótese de Michels}

A partir da análise fundadora de Michels, procura-se compreender as relações entre a organização interna dos partidos e suas características ideológicas. Esta pesquisa apresenta uma abordagem da lei de ferro da oligarquia para a América Latina. Nela, a lei de ferro é apreendida como a tendência para moderação ideológica entre os partidos que se tornam organizacionalmente mais complexos. A pesquisa engloba 62 partidos que participaram de 49 eleições presidenciais em 12 países da América Latina entre 1998 e 2015. A dimensão organizacional é mensurada por meio do tempo de funcionamento do partido e tamanho de suas bancadas parlamentares. A ideologia programática é apreendida por meio de análise de conteúdo dos programas de governo das eleições presidenciais. A pesquisa permite observar que o conjunto de agremiações de esquerda comporta-se conforme o predito pela lei de ferro. $\mathrm{O}$ aspecto organizacional não é suficiente para explicar, sozinho, as razões da mudança ideológica. Aparece, contudo, no cômputo de recursos e circunstâncias que permitem e restringem as estratégias disponíveis aos líderes partidários na busca pelo poder. Na medida em que reforça a permanência da lei de ferro da oligarquia como elemento explicativo das ideologias partidárias, a pesquisa também avança na compreensão do fenômeno partidário latino-americano.

Palavras-chave: partidos políticos; organização; Robert Michels; ideologia; América Latina

\section{ABSTRACT: \\ Organization and Ideology in Latin American Parties: an Approximation of the Michels Hypothesis}

Taking into consideration the founding analysis of Michels, one tries to understand the relations between the internal organization of the parties and their ideological characteristics. This research presents an approach to the iron law of the oligarchy in Latin America. In it, the iron law is understood as the tendency for ideological moderation among the parties that become organizationally more complex. The survey encompasses 62 parties that participated in 49 presidential elections in 12 Latin American countries between 1998 and 2015. The organizational aspect is measured by party running time and the size of its parliamentary seats. The programmatic ideology is examined through content analysis of the presidential election governance programs. The research shows that the set of left-wing associations behaves as predicted by the iron law. The organizational 


\section{Augusto Neftali Corte de Oliveira}

aspect alone is not enough to explain the reasons for ideological change. It appears, however, in the sum of resources and circumstances that allow and restrict the strategies available to partisan leaders in the quest for power. Insofar as it reinforces the permanence of the iron law of the oligarchy as an explanatory element of party ideologies, the research also advances in the understanding of the Latin American partisan phenomenon.

Keywords: political parties; organization; Robert Michels; ideology; Latin America

\section{RÉSUMÉ}

L'Organisation et l'Idéologie aux Partis de L'Amérique Latine: une Approximation de l'Hypothèse de Michels

De l'analyse fondatrice de Michels, on cherche à comprendre les relations entre l'organisation interne des partis et leurs caractéristiques idéologiques. Cette recherche présente une approche de la loi de fer de l'oligarchie pour l'Amérique Latine. Dans ce cadre, la loi de fer est perçue comme une tendance à la modération idéologique parmi les Partis qui deviennent organisationnellement plus complexes. L'enquête englobe 62 partis qui ont participé à 49 élections présidentielles dans 12 pays de l'Amérique Latine entre 1998 et 2015. La dimension organisationnelle est mesurée par la durée de ses fonctions et de la quantité de ses représentants parlementaires. L'idéologie programmatique est appréhendée à travers l'analyse du contenu des programmes du gouvernement pour l'élection présidentielle. La recherche montre que l'ensemble des associations de la gauche se comporte comme prévu par la loi de fer. L'aspect organisationnel ne suffit pas pour expliquer les raisons du changement idéologique. Cela apparaît toutefois dans le calcul des ressources et des circonstances qui permettent et restreignent les stratégies disponibles pour les leaders partisans dans la quête du pouvoir. Dans la mesure où elle renforce la permanence de la loi de fer de l'oligarchie en tant qu'élément explicatif des idéologies des partis, cette recherche permet également de mieux comprendre le phénomène des partis politiques latino-américains.

Mots-clés: partis politiques; organisation; Robert Michels; idéologie; Amérique Latine 


\section{RESUMEN}

Organización e Ideología en los Partidos de América Latina: una Aproximación de la Hipótesis de Michels

A partir del análisis fundador de Michels, se busca comprender las relaciones entre la organización interna de los partidos y sus características ideológicas. Esta investigación presenta un abordaje de la ley de hierro de la oligarquía para América Latina. La ley de hierro es aprehendida como la tendencia para la moderación ideológica entre los partidos que se vuelven organizacionalmente más complejos. La investigación engloba 62 partidos que participaron de 49 elecciones presidenciales en 12 países de América Latina entre 1998 y 2015. La dimensión organizacional es mensurada por medio del tiempo de funcionamiento del partido y el tamaño de sus bancadas parlamentarias.La ideología programática es aprehendida por medio del análisis de contenido de los programas de gobierno de las elecciones presidenciales. La investigación permite observar que el conjunto de agremiaciones de izquierda se comporta conforme a lo predecido por la ley de hierro. El aspecto organizacional no es suficiente para explicar, por sí solo, las razones del cambio ideológico. Sin embargo, aparece en el cómputo de recursos y circunstancias que permiten y restringen las estrategias disponibles a los líderes partidarios en la búsqueda por el poder. En la medida en que se refuerza la permanencia de la ley de hierro de la oligarquía como elemento explicativo de las ideologías partidarias, la investigación também avanza en la comprensión del fenómeno partidario latinoamericano.

Palabras clave: partidos políticos; organización; Robert Michels; ideología; América Latina 